Annals of Warsaw University of Life Sciences - SGGW

Horticulture and Landscape Architecture No 41, 2020: 29-35

(Ann. Warsaw Univ. of Life Sci. - SGGW, Horticult. Landsc. Architect. 41, 2020)

DOI 10.22630/AHLA.2020.41.3

\title{
Phytotoxicity and phytogenotoxicity of municipal sewage sludge
}

GRAŻYNA OBIDOSKA, ZBIGNIEW KARACZUN, BARBARA ŻARSKA

Institute of Horticultural Sciences, Warsaw University of Life Sciences - SGGW

\begin{abstract}
Phytotoxicity and phytogenotoxicity of municipal sewage sludge. The aim of our research was to evaluate the phytotoxicity and phytogenotoxicity of Warsaw municipal sewage sludge, mixed with two different types of soils, using standard plant bioassays: the Phytotoxkit and the Allium cepa Root Tip Assay. The phytotoxicity of sludge mixtures with soils was influenced by the concentration of sludge and the type of soil. In the case of sludge/sand mixtures, even a 3\% sludge concentration was phytotoxic, whereas in sludge/ /peat substrate mixtures, the phytotoxic effect was observed only in the $25 \%$ concentration. Unfortunately, in this and also a lower $(6 \%)$ concentration of sludge in a sludge/peat substrate mixture, a strong phytogenotoxic effect was noticed. Therefore, the so called biological utilisation of the considered sludge seems rather hazardous for plants, especially in the case of sandy, but also in organic soils.
\end{abstract}

Key words: sewage sludge, phytotoxicity, Phytotoxkit, phytogenotoxicity Allium cepa RTA

\section{INTRODUCTION}

In Poland, especially during the period 2003-2016, the volume of untreated municipal sewage decreased very significantly due to the construction of new treatment plants (403 objects) or modernisation of the old ones (PGW Wody Polskie 2019). It resulted in the improvement of the condition of Polish surface waters (IOŚ 2006, GIOŚ 2018). However, the management of sewage sludge still remains a problem that needs to be resolved. The main method of sludge utilisation is combustion or co-combustion (Niesler and Nadziakiewicz 2013), but there are also attempts to use it, under certain conditions and restrictions (Rozporządzenie Ministra Środowiska z 2015 r. w sprawie komunalnych osadów ściekowych), in agriculture (Wiater and Butarewicz 2014, Snarska 2015) or land reclamation. Sewage sludges contain organic matter and nutrients, but, on the other hand, are likely to be contaminated with heavy metals, polycyclic aromatic hydrocarbons (PAHs) and other constituents (Oleszczuk 2008). Many authors have reported the phytotoxicity or phytogenotoxicity of municipal sewage sludges (Srivastava et al. 2005, Oleszczuk 2008, Oleszczuk et al. 2012, El Fels et al. 2015, Correa-Martins et al. 2016a). However, one should keep in mind that they may vary significantly depending on their origin. Therefore, a detailed characteristic (and current monitoring) of the particular sludge must be the basis for selecting the way of its utilisation (Bauman-Kaszubska and Sikorski 2014).

The sludges from Warsaw sewage treatment plants were combusted until December, 2018. This method unfortunately had to be temporarily suspended 
due to the failure of the combusting devices (MPWiK 2019); and other methods of utilisation need not only a chemical analysis and sanitary status assessment of the sludge, but also toxicity and genotoxicity studies. The aim of our research was to evaluate the phytotoxicity and phytogenotoxicity of the Warsaw municipal sewage sludge, mixed with two different types of soils, using standard plant bioassays.

\section{MATERIAL AND METHODS}

Granulated, stabilised municipal sewage sludge from the "Południe" sewage treatment plant in Warsaw was the object of our study. The treatment plant is situated in the south of the city, in the Wilanów District. It treats daily about $60,000 \mathrm{~m}^{3}$ of sewage originating from the southern part of Warsaw located on the left bank of the Vistula river.

\section{Phytotoxicity testing}

A seed germination and root elongation test was performed in pots, using a $100 \%$ moist sludge and peat substrate as a control. Eight species of plants were sown: pea, soy, beans, radish, mustard, cress, rye and wheat, and the inhibition of seed germination $(S G I)$ and root elongation $(R E I)$, in relation to the control, was calculated using the following formula:

$S G I / R E I=C-B / C \cdot 100(\%)$

$C$ - mean seed germination/root elongation in the control peat substrate, $B$ - mean seed germination/root elongation in the sludge.

In the second stage of the study, the sludge was mixed with a sand or peat substrate to obtain the concentrations of $3 \%, 6 \%$ and $25 \%(\mathrm{v} / \mathrm{v})$. Toxicity was assessed with a standard bioassay - the Phytotoxkit (Phytotoxkit 2004). Fifteen garden cress seeds (Lepidium sativum) were placed in Phytotoxkit plates filled with the above listed sludge/sand or sludge/peat substrate mixtures. The incubation in $25^{\circ} \mathrm{C}$, in the dark, lasted three days and subsequently seed germination and root length were measured. Also the $\mathrm{EC}_{50}$ values were calculated (effective concentrations of sludge in the sand and peat mixtures, in which seed germination and root elongation were inhibited by $50 \%$ in comparison to the control ones).

\section{Phytogenotoxicity testing}

In the third stage of the study, phytogenotoxicity was evaluated using the Allium cepa Root Tip Assay. Prepared Allium bulbs were placed in beakers with tap water to obtain about $2 \mathrm{~cm}$ long adventitious roots. The roots were incubated for three days in a peat substrate (control) and $3 \%, 6 \%$ and $25 \%(\mathrm{v} / \mathrm{v})$ sludge/peat substrate mixtures. Next they were collected, fixed in Carnoy's solution and stored in $70 \%$ ethanol. For microscopic slide preparation, the roots were macerated in $1 \mathrm{M} \mathrm{HCl}$ for $20 \mathrm{~min}$, stained in acetoorcein, and the root tips squashed under a cover glass. Mitotic indices $(M I)$ and micronuclei frequencies $(M C N)$ were scored per 1,000 meristematic cells (in three replications per concentration).

The results, presented as means \pm standard deviations, were subjected to a one way analysis of variance (ANOVA) and Tukey post hoc test, with statistical significance set at $p=0.05$ (Statistica 13.3). 


\section{RESULTS AND DISCUSSION}

The $100 \%$ sewage sludge was highly phytotoxic for eight species of plants used in the experiment (Fig. 1). Seed germination was nearly totally inhibited in beans, radish and mustard (90-100\%), in the case of peas, cress and wheat by about $70 \%$, and in rye by only $22 \%$. Sensitivity of plant species towards various contaminants is different. For example monocotyledons, such as rye, are generally more resistant than dicotyledons (De Oliveira et al. 2016) to heavy metals, which are very probable in sludges. However, root elongation, which is a more sensitive phytotoxicity testing parameter (An 2004), was reduced by $95-100 \%$ in each of the tested species.

As soil amendments, sludges are mixed with soils in certain proportions. In the study we prepared three concentrations: 25,6 and $3 \%$, which was recommended for Granbial, an organic fertilizer prepared on the basis of sewage sludge from the Białystok agglomeration (Snarska 2015). Because different sludge results have been reported in various types of soils (Romanowska-Duda and Grzesik 2008, Oleszczuk et al. 2012), the mixtures with sand, and with a peat substrate were tested. The results differed significantly (Figs. 2 and 3). In peat mixtures, the sludge in the tested concentrations had no negative influence on seed germination. Even the elongation of roots was significantly reduced only in the highest, $25 \%$ concentration. Sludge mixtures with concentration of 6 and 3\% did not inhibit the growth of roots, but they did not stimulate it either.

The effect was substantially different in sludge/sand mixtures; seed germination was slightly affected even in $3 \%$ sludge $(12 \%$ reduction). In $6 \%$ sludge, the germination was reduced by $70 \%$,

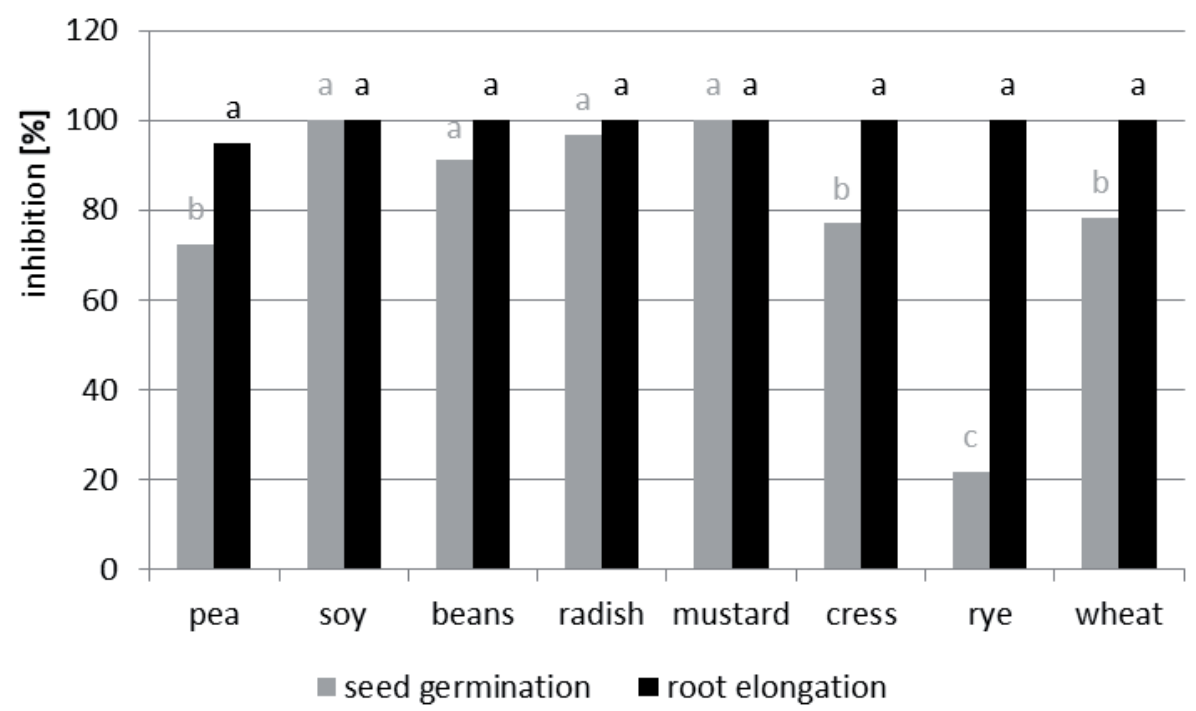

FIGURE 1. Inhibition of seed germination and root elongation by $100 \%$ sludge in various plant species (means marked with the same letter, within the same parameter, do not differ significantly) 


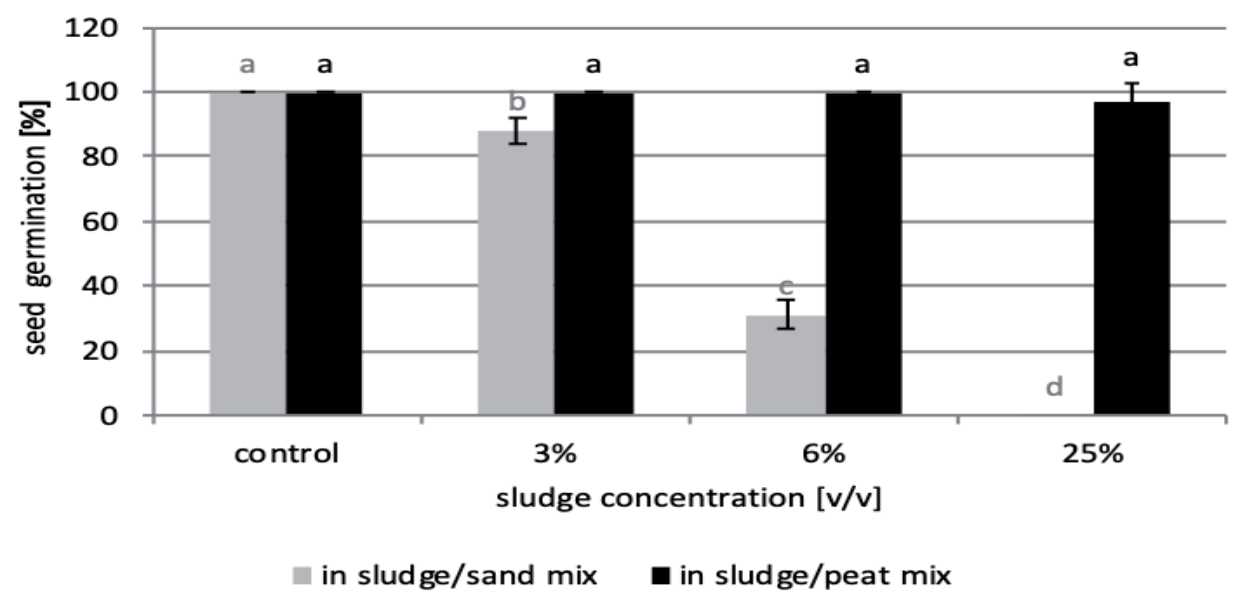

FIGURE 2. Effect of sludge concentrations in sludge/sand and sludge/peat substrate mixtures on the seed germination of Lepidium sativum (means marked with the same letter, within the same sludge mixture, do not differ significantly)

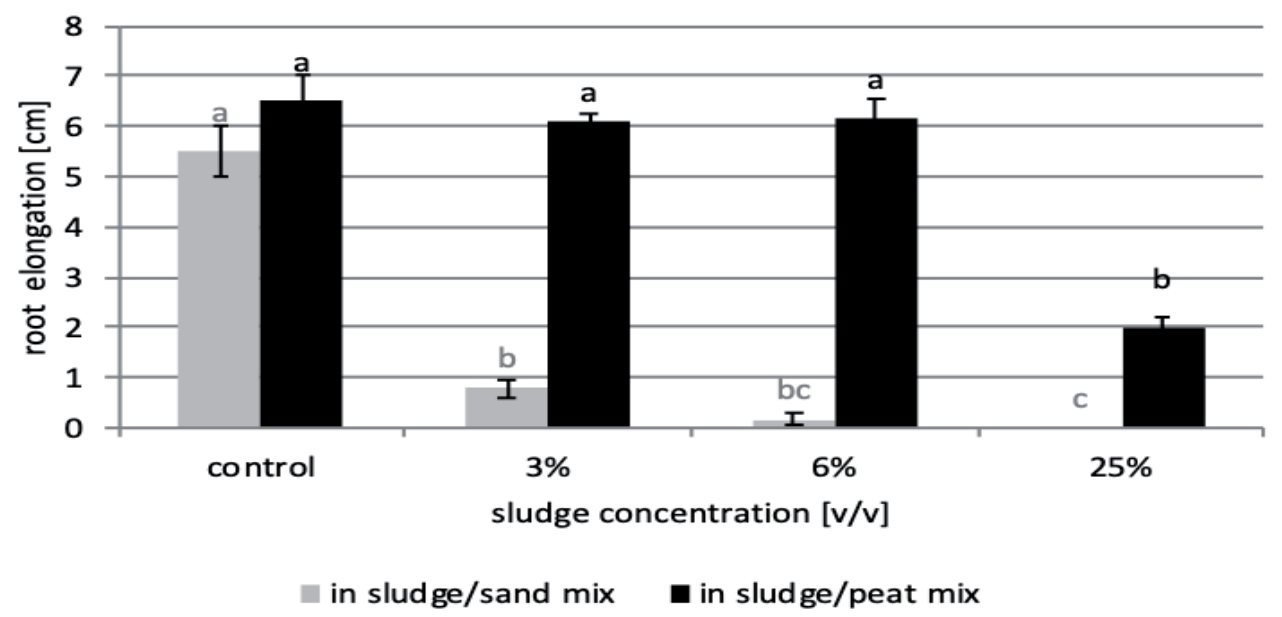

FIGURE 3. Effect of sludge concentrations in sludge/sand and sludge/peat substrate mixtures on the root elongation of Lepidium sativum (means marked with the same letter, within the same sludge mixture, do not differ significantly

and in $25 \%$ sludge by $100 \%$. Root elongation was inhibited very significantly even in the lowest, $3 \%$ concentration, and in the $25 \%$ concentration the roots did not appear at all. The calculated $\mathrm{EC}_{50}$ values for sludge/peat and sludge/sand mixtures are given in the table.
Because the phytotoxicity of even 3\% sludge in a sludge/sand mixture seemed hazardous enough for the plants, phytogenotoxicity studies with Allium cepa RTA were undertaken only for the less toxic sludge/peat mixtures. The inhibition of mitosis or phytogenotoxicity of 
TABLE. Values $\mathrm{EC}_{50}$ of for sludge/sand and sludge/peat substrate mixtures evaluated by two parameters for phytotoxicity assessment: seed germination and root elongation of Lepidium sativum seedlings

\begin{tabular}{|l|c|c|}
\hline Parameter & $\begin{array}{c}\text { Sludge concentration } \\
\text { in sludge/sand mix } \\
(\%)\end{array}$ & $\begin{array}{c}\text { Sludge concentration } \\
\text { in sludge/peat mix } \\
(\%)\end{array}$ \\
\hline Seed germination & 4.8 & $>25$ \\
\hline Root elongation & $<3$ & 17 \\
\hline
\end{tabular}

the $3 \%$ sludge concentration was not observed, but in the $6 \%$ and $25 \%$ sludges, the mitotic index was significantly reduced and micronuclei appeared in the root tip cells. In $6 \%$ sludge we noted about $20 \%$ of interphase cells with one or two micronuclei $(M C N)$. The situation was much worse in the $25 \%$ sludge/ peat mixture: in about $33 \%$ of interphase cells, multiple micronuclei were observed (Fig. 4).

Other authors (Srivastava et al. 2005 , Correa-Martins et al. 2016b) have also reported the municipal sewage sludges genotoxic properties. Toxicity and geno- toxicity may be caused by various components of a sludge, such as heavy metals or PAHs. Exceeded levels of heavy metal contamination of a sludge produced by a great agglomeration are very probable (Bień et al. 2011). The lower phytotoxicity observed in sludge/peat mixtures than in sludge/sand ones, might be the result of the reduced availability of metals, due to their immobilisation by the organic matter (Ociepa et al. 2014) of the peat substrate

The method of sewage sludge utilisation should be dedicated to the particular type of sludge. In some cases the usage

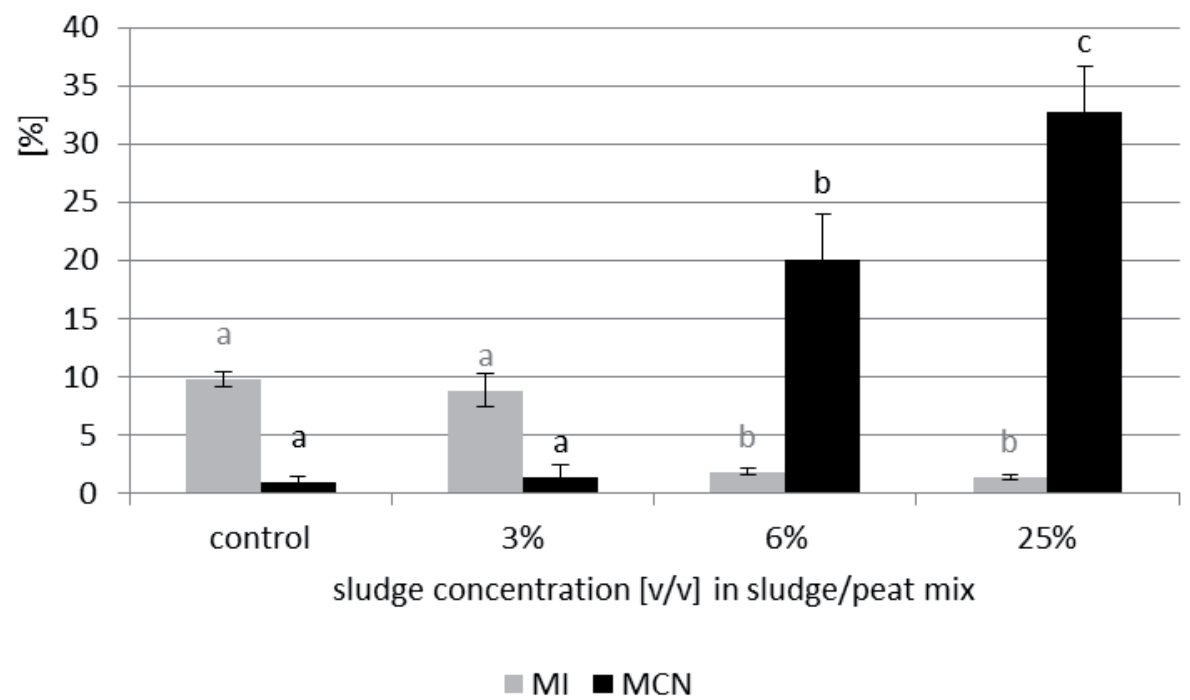

FIGURE 4. Effect of sludge concentrations in sludge/peat substrate mixtures on the mitotic index $(M I)$ and micronuclei frequency $(M C N)$ in Allium cepa root tip meristematic cells (means marked with the same letter, within the same parameter, do not differ significantly) 
as organic fertilizers is pointless or even hazardous (Correa-Martins 2016b), but in some others, the effect on plant biomass production may be encouraging (Rosikoń 2014). Biological utilisation in the case of the sludge considered in our study seems rather risky, especially in sandy soils. The process of the composting of sewage sludges may, however, reduce their phytotoxicity (Oleszczuk 2008).

\section{CONCLUSIONS}

1. The phytotoxicity of sludge mixtures with soils was influenced by the concentration of sludge in a mixture and the type of soil.

2. In the case of the sludge/sand mixtures, even 3\% sludge concentration was phytotoxic, while in sludge/peat mixtures the phytotoxic effect was observed only in the highest, $25 \%$ sludge concentration.

3. Unfortunately, even in the $6 \%$ concentration of sludge in a sludge/peat mixture, a strong phytogenotoxic effect was noted.

4. Utilisation of the considered sludge as soil amendment may be hazardous for plants, especially in sandy soils.

\section{Acknowledgements}

We would like to thank Miejskie Przedsiębiorstwo Wodociągów i Kanalizacji (MPWiK) for granting the sewage sludge sample for the studies.

\section{REFERENCES}

AN Y. 2004: Soil ecotoxicity assessment using cadmium sensitive plants. Environ. Pollut. 127: 21-26.
BAUMAN-KASZUBSKAH., SIKORSKIM. 2014: Conditions of agricultural and natural use of sewage sludge in rural areas. Inż. Ochr. Środ. 17 (1): 105-115.

BIEŃ J., NECZAJ E., WORWĄG M., GROSSER A., NOWAK D., MILCZAREK M., JANIK M. 2011: Kierunki zagospodarowania osadów w Polsce po roku 2013. Inż. Ochr. Środ. 14 (4): 375-384.

CORREA-MARTINS M.N., de SOUZA V.V., da SILVA SOUZA T.D.S. 2016a: Genotoxic and mutagenic effects of sewage sludge on higher plants. Ecotoxicol. Environ. Saf. 124: 489-496.

CORREA-MARTINS M.N., de SOUZA V.V., da SILVA SOUZA T.D.S. 2016b: Cytotoxic, genotoxic and mutagenic effects of sewage sludge on Allium cepa. Chemospere 148: 481-486.

De OLIVEIRA V.H., MELO L.C.A., ABREU C.A., COSCIONE A.R. 2016: Influences of soil $\mathrm{pH}$ on cadmium toxicity to eight plant species. Ecotoxicol. Environ. Contam. 11 (1): 45-52.

El FELS L., HAFIDI M., SILVESTRE J., KALLERHOFF J. 2015: Efficiency of co-composting process to remove genotoxicity from sewage sludge with hexavalent chromium. Ecol. Eng. 82: 355-360.

Główny Inspektor Ochrony Środowiska - GIOŚ 2018: Stan środowiska w Polsce. Raport 2018. Biblioteka Monitoringu Środowiska. GIOŚ, Warszawa.

Inspekcja Ochorny Środowiska - IOŚ 2006: Stan środowiska w Polsce na tle celów i priorytetów Unii Europejskiej. Raport wskaźnikowy 2004. Biblioteka Monitoringu Środowiska. IOŚ, Warszawa.

Miejskie Przedsiębiorstwo Wodociągów i Kanalizacji - MPWiK 2019: Informacja MPWiK dotycząca stacji termicznej utylizacji osadów ściekowych STUOS ( $\mathrm{z}$ dnia 19.09.2019). Retrieved from: https://www.mpwik.com.pl/view/informacja-mpwik-dotyczca-stacji-termicznej-utylizacji-osadow-sciekowych-stuos [accessed: 30.12.2019].

NIESLER J., NADZIAKIEWICZ J. 2013: Ocena możliwości współspalania odpa- 
dów komunalnych i osadów ściekowych w aglomeracji śląskiej. Piece Przemysłowe i Kotły 9-10: 29-41.

OCIEPA E., PACHURA P., OCIEPA-KUBICKA A. 2014: Wpływ niekonwencjonalnego nawożenia na migrację metali ciężkich w układzie gleba-roślina. Inż. Ochr. Środ. 17 (2): 325-338.

OLESZCZUK P. 2008: Phytotoxicity of municipal sewage sludge composts related to physico-chemical properties, PAHs and heavy metals. Ecotoxicol. Environ. Saf. 69: 496-505.

OLESZCZUK P., MALARA A., JOŚKO I., LESIUK A. 2012: The phytotoxicity changes in sewage sludge amended soils. Water Air Soil Pollut. 223 (8): 4937$-4948$.

PGW Wody Polskie 2019: Krajowy program oczyszczania ścieków komunalnych. Retrieved from: https://www.kzgw.gov. $\mathrm{pl} /$ index.php/pl/materialy-informacyjne/ /programy/krajowy-program-oczyszczania-sciekow-komunalnych [accessed: 21.12.2019].

Phytotoxkit 2004: Seed germination and early growth microbiotest with higher plants. Standard Operational Procedure. MicroBioTest Inc., Nazareth.

ROMANOWSKA-DUDA Z.B., GRZESIK M. 2008: Zastosowanie pomiarów biometrycznych roślin $\mathrm{w}$ monitorowaniu środowiska i produkcji biomasy do celów energetycznych. In: Ekotoksykologia w ochronie środowiska. PZITS, Oddział Dolnośląski, Wrocław.

ROSIKOŃ K. 2014: Osady ściekowe w nawożeniu wybranych roślin energetycznych. Inż. Ochr. Srod. 17 (2): 339-348.

Rozporządzenie Ministra Środowiska z dnia 6 lutego 2015 r. w sprawie komunalnych osadów ściekowych. Dz.U. 2015, poz. 257.

SNARSKA K. 2015: Nowe źródło substancji organicznej. Wiad. Rol. 1: 22.

SRIVASTAVA R., TEWARI A., CHAUHAN L.K., KUMAR D., GUPTA S.K. 2005: Ecotoxicological evaluation of municipal sludge. Altern. Lab. Anim. 33 (1): 21-27.
WIATER J., BUTAREWICZ A. 2014: Sposoby wykorzystania osadów z Oczyszczalni ścieków w Białymstoku. Inż. Ochr. Środ. 17 (2): 281-291.

Streszczenie: Fitotoksyczność i fitogenotoksyczność komunalnych osadów ściekowych. Celem badań była ocena fitotoksyczności i fitogenotoksyczności warszawskich komunalnych osadów ściekowych zmieszanych $\mathrm{z}$ dwoma różnymi rodzajami gleb przy użyciu standardowych biotestów roślinnych: Phytotoxkit i Allium cepa Root Tip Assay. Fitotoksyczność mieszanin osadów z glebami była zależna od koncentracji osadu i rodzaju gleby. W przypadku mieszaniny osadu z piaskiem już 3\% koncentracja działała fitotoksycznie, podczas gdy mieszanina $\mathrm{z}$ substratem torfowym wywoływała efekt fitotoksyczny dopiero przy 25-procentowym stężeniu osadu. Niestety przy tym, a także niższym (6\%) stężeniu osadu $\mathrm{w}$ mieszaninie $\mathrm{z}$ substratem torfowym stwierdzono silny efekt fitogenotoksyczny. Wydaje się zatem, iż tak zwane biologiczne wykorzystanie badanego osadu ściekowego jest raczej ryzykowne dla roślin, szczególnie w przypadku gleb piaszczystych, ale także organicznych.

Słowa kluczowe: osady ściekowe, fitotoksyczność, Phytotoxkit, fitogenotoksyczność, Allium сера RTA

MS received: 31.12 .2019

MS accepted: 03.07.2020

Authors' address:

Grażyna Obidoska (https://orcid.org/0000-0003-3046-0086)

Zbigniew Karaczun

(https://orcid.org/0000-0001-6971-275X)

Barbara Żarska

(https://orcid.org/0000-0001-5341-1557)

Katedra Ochrony Środowiska i Dendrologii Instytut Nauk Ogrodniczych

Szkoła Główna Gospodarstwa Wiejskiego

w Warszawie

ul. Nowoursynowska 159, 02-776 Warszawa

Poland

e-mail: grazyna_obidoska@sggw.edu.pl 